$\left(\begin{array}{lll}\text { Jpn. J. Hosp } & \text { Pharm. } \\ \text { 技 } & \text { 術 } & \text { 報 } \\ 23(1) & 75-81 & (1997)\end{array}\right)$

PC 処方オーダエントリシステムの問題点と利点

二橋純一 $\dagger^{1}$ ，西川三喜男 $\dagger^{1}$ ，鈴木吉成 $\dagger^{1}$ ，橋本久邦 $\dagger^{1}$ ，谷 重喜 $\dagger^{2}$ ，木村通男 $\dagger^{2}$ ，菅野剛史 $\dagger^{2}$ 浜松医科大学医学部附属病院薬剤部 ${ }^{1}$

浜松医科大学医療情報部 ${ }^{2}$

\title{
Problems and Efficiencies of PC-order Entry System for Prescription
}

\author{
JUN-ICHI NIHASHI $\dagger^{+}$, MIKIO NISHIKAWA $\dagger^{+}$, YOSHINARI SUZUKI $\dagger^{+}$, HISAKUNI HASHIMOTO $\dagger^{1}$, \\ SHIGEKI TANI $\dagger^{2}$ and TAKASI KANNO $\dagger^{2}$ \\ Department of Pharmacy, Hamamatsu University School of Medicine $\dagger^{1}$ \\ Department of Medical Informatics, Hamamatsu University School of Medicine $\dagger^{2}$
}

\author{
$\left(\begin{array}{lc}\text { Received January } 29, & 1996 \\ \text { Accepted November } 7, & 1996\end{array}\right)$
}

We have converted our hospital information system used in Hamamatsu University School of Medicine from a host on-line system to a client-server system (PC-ordering). Problems and efficiencies in the use of this new order entry system for prescriptions were subsequently evaluated.

Several merits were identified such as contraindicational drug use, drug interaction and duplication checking systems, but many problems still remain to be overcome in the PCordering system package produced by NEC.

We classified these problems into three categories. (1) data transfer problems, (2) system conversion problems, and (3) client-server system problems.

Key words — system conversion, PC-ordering system, prescription, real-time prescription check

\section{緒 言}

近年, 電算システムのダウンサイジング化が行 われている。浜松医科大学附属病院においても平 成 7 年 1 月から, 病院情報システムの更新が行わ れ，ホストコンピュータ集中系から分散型アーキ テクチャーの導入が図られ, クライアント・サー

$\dagger^{1.2}$ 静岡県浜松市半田町 3600 , Handa-cho, Hamamatsu-shi, 431-31 Japan
バー型のネットワーク構成が採用された。これに より, 従来システムと比較して端末系の機能が大 幅に増強され，ホスト系の負担が極めて軽いもの となる予定であった。また，分散型アーキテクチ ヤ一の採用と共に水平連携の強化，標準化を推進 した。このことは個々のサブシステムの保守性を 向上させ，部分的機能それぞれにおける独自の開 発を可能とするものであり，マルチベンター化の 第一歩であると考えた。システム変更時には現行 
システムとの比較をしながら, 重要な機能がもれ ないように注意していく必要があり, ベンダーに そのことは伝達し, 応札仕様書にも記載しておい た。このことは処方オーダエントリシステムに限 らず，検査関連システム，放射線関連システム， 看護関連システムにおいても同様なことがいえ る.しかし，ベンダー側の用意してきたシステム はパッケージ化されたものにほとんど修正がなさ れていなかったため, 多くの問題点を生じた。 こ こでは本院における処方オーダエントリシステム 移行時の問題点と利点について述べる.

\section{1. システム構成}

システムはメインフレームとして ACOS 3600 モデル10, サーバーとして EMS4800（37台）, 端末として PC9821（399台）から構成されてい る.これらが病院 LAN に接続され，情報の伝 達を行っている（図1）。

\section{2. グレードアップ時の問題点}

浜松医科大学附属病院では昭和63から処方オー ダエントリシステムをホスト集中型（52系専用端 末ーメインフレーム) で行ってきた。 今回, 分散 型（PC 端末ーワークステーションーメインフレ 一ム）アーキテクチャーを導入することが決定さ れ, 処方オーダデータ移行を初め各種プログラム の PC 系への移植が開始された.この中で様々 な問題点が浮かび上がり, それを大きく 3 グルー プに分類した。

1 ）データ移行に関する問題点

データ移行についての問題点を列記すると次の ようになる。

（1）薬品名を筆頭に用法, コメントの文字数 が52系よりも 4 バイトも少ないため, 完全に出 力できないのみならず，データ表示（前回処方 など）についてはさらに文字数が少なくしてあ るので (18バイト， 9 文字表示), 途中で切れて しまうものがかなりでてきた。

（2）半角文字が移行されず，半角で入力され ていた薬品名, 規格やコメントが消えてしまっ
た.

（3）コメントが文字化けをおこし，解読でき ないものがあった。従来はコメントであった不 均等分割は新システムでは用法に属している が, 分 4 のものがすべて文字化けをおこした.

(4) 不均等分割の指示が画面では表示されて いるのに，処方せんには出力されない．

（5）移行が不完全な処方データを流用しオー ダ入力した場合, 登録されたが, 処方せんの出 力がなかった。しかもこの不正に登録されたデ 一タは照会も取消しもできず，データベース上 にゴミとして残ってしまった。このため、デー タのダウンロードまで不可能となってしまっ た.

2 ）システム移行に関する問題点

次にシステム移行についての問題点を述べる が，入札から納入までの時間的余裕が少なかった ことに主な原因があると思われる。このため， ユ ーザー側の要望に対応がなされないままパッケー ジ化されたシステムを導入し，次のような様々な 問題点が生じてしまった。

（1）処方オーダ用薬剤マスタにおいて，6枌 の数字コードを使用しているが, 先頭の数字が “2”のものしか認識せず, 注射薬, 院内製 姷, 治験薬および器具などが検索できなかっ た。

（2）内服散剤（錠剤粉砕化を含む）,液剤の用 量が用法チェックにかかり，入力できない(コ ランチル顆粒 $2 \mathrm{~g}$ 分 3 等).

(3) 薬骫コメントはこれまで剤型ごとにあっ たものが 1 レコードしかなく，しかも自動的に コメントへ移行する機能もなくなった。このた め, 点眼薬や注射薬の用法入力方法を変更する 必要が生じた。

（4）処方日数を一括して変更する機能がなか った.

（5）DO 処方の際, 処方流用方法が従来シス テムと異なっていた．自科の前回処方だけを流 用する場合はさほど差異はないが，二種以上の 


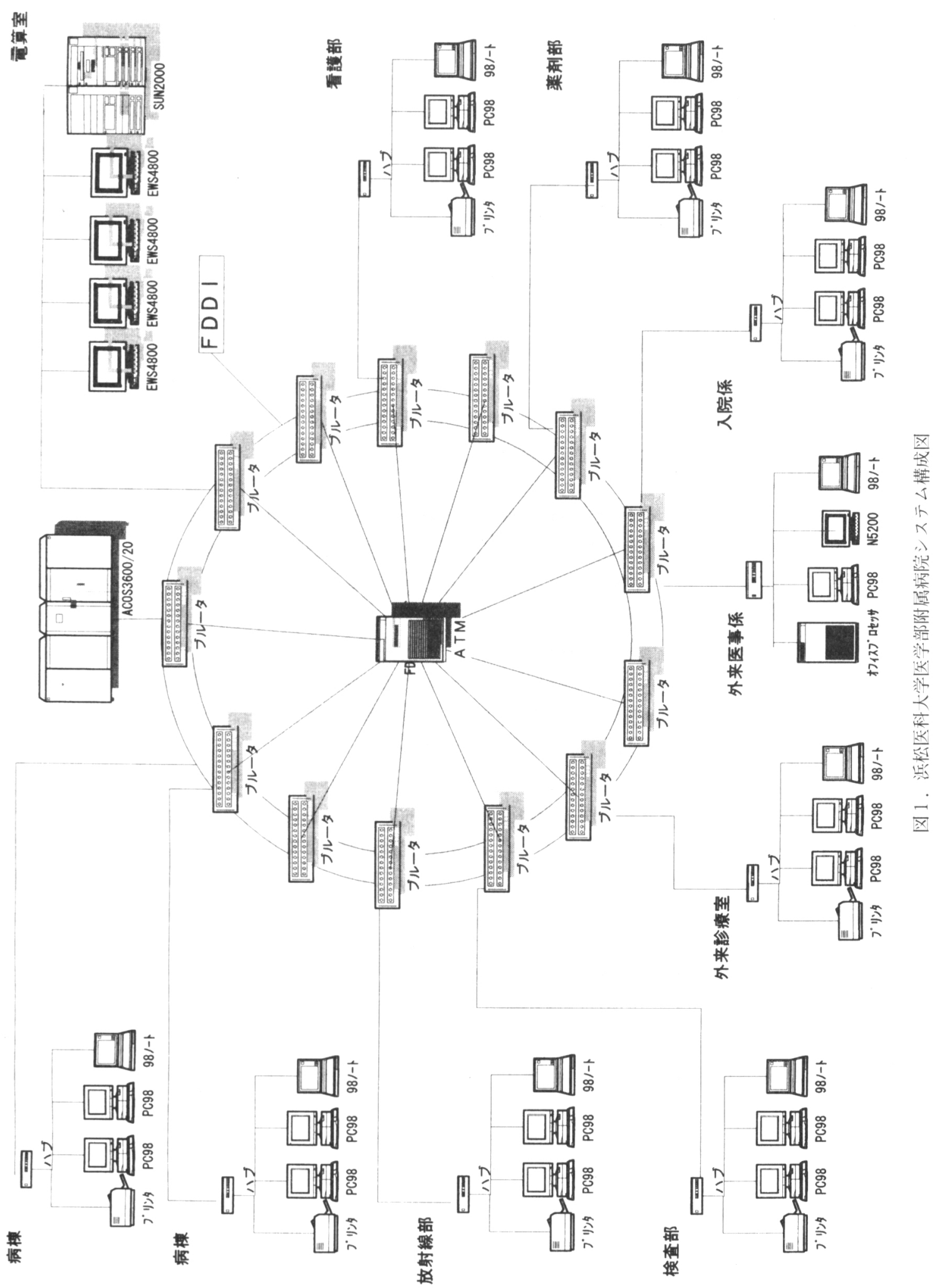


データを流用しようとすると操作回数が大幅に 増加してしまう。

（6）旧システムでは他科処方も自動表示して いたので，医師は処方の時患者にどのような薬 剤が既に処方去さていたかを容易に確認できて きたが，本システムではそれを指定して画面に 表示させなくてはならなくなった.

（7）プルダウンメニューのため，行いたい業 務に到達するのに何度も画面展開をしなくては ならなくなった。しかも患者 ID 引き継ぐ システムもなくなったので，その都度患者 ID の入力が必要となった。

（８）錠剤自動分包器への送信が個々の患者ご とに行えず，一包化中止などは錠剤分包器側で 行うこととなった。 また, 分包器への送信しな いはずのデータ（錠剤分割・粉砕化，用法が医 師の指示どおりなど）の分離が不完全であっ た.

これらが主な問題点であった。この内，

（1），(2)と（8）のデータ分離は本番稼働時ま でに修正された。しかし，修正の間に合わない

（3），（4）や（８）の個別送信機能は平成 7 年12 月までに修正された。その他の項目（5)，(6) と（7）は現在の日本電気の PC オーダエントリ システムでは対応が困難であり, システム改造に は時間を要するとの回答であった。こうしたこと から結果的にはレベルダウンした印象を医師およ び薬浏師に持たせてしまったといえる。

3 ) クライアント・サーバ型分散システムに関 する問題点

現在の分散システムではデータ配信が 1 日 1 回, 夜間に行われているが, 病院情報システムに おいてこの方法は次の理由から不適当と考えられ る。

（1）データ配信が 1 日 1 回では緊急の対応が とれないこと.

（2）入力したデータが正しく表示され, 正し く伝達されているのかが確認できない。このこ とは患者生命に係わる問題が生じる危険性を含
んでいる.

（3）どの端末にも同一の等しいデータが配信 されなくてはならないのに端末により配信され ないデータがある。

このような問題点は本院で初めて明らかになっ たものではないと考えられるが，他施設では問題 にされなかったのであろうか。データ配信方法は 速やかに改善されるべき問題であるといえる。

以上，問題点を列記したが，データ移行に関し てはデータベース構造，特に各種マスターファイ ルが問題となることが多い.これらマスターファ イルの特性としてコンピュータ相互間において互 換性がない場合が少なくない。この非互換性の原 因として, 英数文字コード体系, 漢字コード体 系, 外字コード体系, 文字の保持領域などが挙げ られる。こうした非互換性のため，薬剤システム で必要となる楽剤名称や各種コメントの文字列を 登録してあるマスターファイルの移行時に問題が 生じる。現象としては文字化け，文字欠け，数値 の桁異常, 単位異常, データ消失などがある。こ れらは基本的なことがらでユーザー，ベンダー双 方が注意をしていれば起こらなかったものと考え られる。

システム移行に関してはいわゆる標準版からユ 一ザーの要望によりカスタマイズした部分の移行 に問題点が多く発生している。例えば，画面が自 動的にコメントへ遷移し，それをそのまま用法と して用いること，他科処方を前回の当該科処方と 並べて表示する機能や錠剤自動分包器への患者ご との送信がそれにあたる。これらは病院のシステ ム運用に基づいてもともとある機能を手直したも のである。これらは前述したマスターファイルの 異常も一つの原因となっている，各施設において も運用に沿って修正したシステムにおいては移行 に関して十分な注意が必要と思われる.

現在のクライアント・サーバー型システムその ものが病院情報システムとして十分機能するもの かどうかの議論はもっとなされるべきであると考 える，従来型の中央集中型システムに比べてマス 
タファイルが増加することが多い。これはクライ アント側とサーバー側のコンピュータが異なるた めに, 各種文字コード体系の不整合性を補う目的 で，両者むけのマスターファイルの作成と管理が 必要となるからである。こうした複雑さがあるた めにデータ配信が必要となり，入力したものがす ぐに確認できないことになる．このことはどのべ ンダーのものでも共通であり, クライアント・サ 一バー型システムの一つの弱点であると思われ る.

\section{3. 新システムの利点}

新システムは確かに問題点は多いが, 次の機能 は従来システムにはなかったもので，それなりの 評価を受けている。

\section{1）薬物療法における副作用の軽減}

薬物療法における副作用の軽減には情報の正確 ですばやい伝達, 併用禁忌薬・相互作用チェック および重複投与のチェックの 3 点がシステムでサ ポートできることであると考えた。

\section{（1）情報伝達について}

薬棛部から主に医師当てに情報を伝達するメイ ル機能の充実を図った。メイルは全職員向けのも の，診療科指定のもの，医師個人を指定するもの および複数指定を可能とすることとした。このメ イル機能を使って厚生省副作用情報やメ一カーか ら出された緊急情報を医師に伝達することとし た。文書による伝達だけでなく，メイルも併用し ていくと便利であると思われる.

（2）併用禁忌, 相互作用チェックについて 一枚の処方せんにおける併用禁忌は当然薬剤師 の果たすべき義務であるが，複数の処方せんにお けるチェックは不可能と言わざるを得ない。これ が可能なのは入院患者で服薬指導管理料を算定し ている（薬歴をつけている）場合に限られる。そ こで, システムによるチェック機構が必要とな る。本システムでは現在患者が服用している薬剤 すべてをチェックの対象とした（アクティブチェ ック).

併用禁忌チェックでは図 2のように同一処方せ
ん上でエリスロシンとトリルダンを処方しようと すると, 薬品名を選択した時点でチェックがかか る. 先にエリスロシンが処方されていて，その投 薬期間中にトリルダンを処方しようとした場合は 日数入力時点でチェックがかかり入力不可とな る.医師はその薬剤を中止し，他の同効医薬品を 選択しなおすことになる。

相互作用についても併用禁忌と同様なチェック をかけることが可能である．先にクラビットが処 方されている患者にアルサミンを処方しようとし た場合の例を示した。図 3 のように相互作用があ るというチェックがかかり，警告が発せられる. 禁忌ではないので, 入力不可とはしないこととし た.

現在，禁忌や相互作用の詳細情報を表示する機 能はないので, 医楽品情報表示画面を呼び出し て, 内容を参照してもらっている。

(3) 重複投与チェック機構について

（2）と同様，現在患者が服用中で，同一の薬 骭が重複する場合, 警告を発生させるシステムと した。初期は無条件で，このチェックをかけてい たが，患者の都合で投与期間中に再受診する事が 多く, 同一診療科における重複チェックは行わな いように変更した（図４）。

（1）〜（3）により，一層安全な薬物療法が 行える手助けをシステムがサポートできるように なったと考えられる.（1）については入手したテ キストファイルの情報そのまま読み込むことので きるシステムアップを計画中である。（2）は禁 忌や相互作用の詳細情報が表示できるよう改造予 定である。

2) 院外処方発行システムについて

新システムに移行と同時に院外処方対象診療科 を全科に拡張した。それに伴い，院外処方発行シ ステムの見直しも次の点について行った。

(1) 院外処方発行プリンターの増設

各診療科の受付に 1 台しかなかったプリンター を 2 診療机に 1 台は配置した。これにより，医師 の手元に近いところに院外処方せんが出力される 

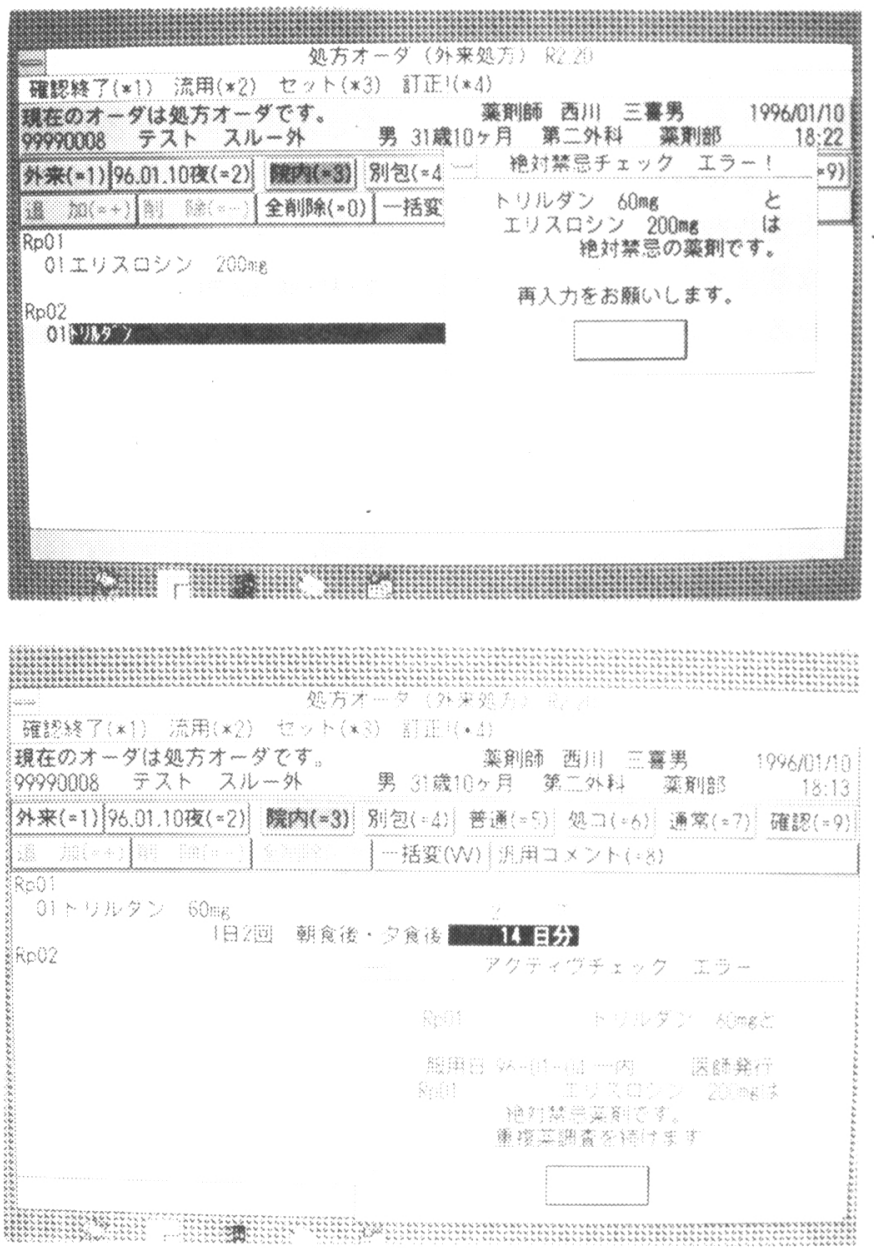

\section{四2，併用禁忌千ェック例}

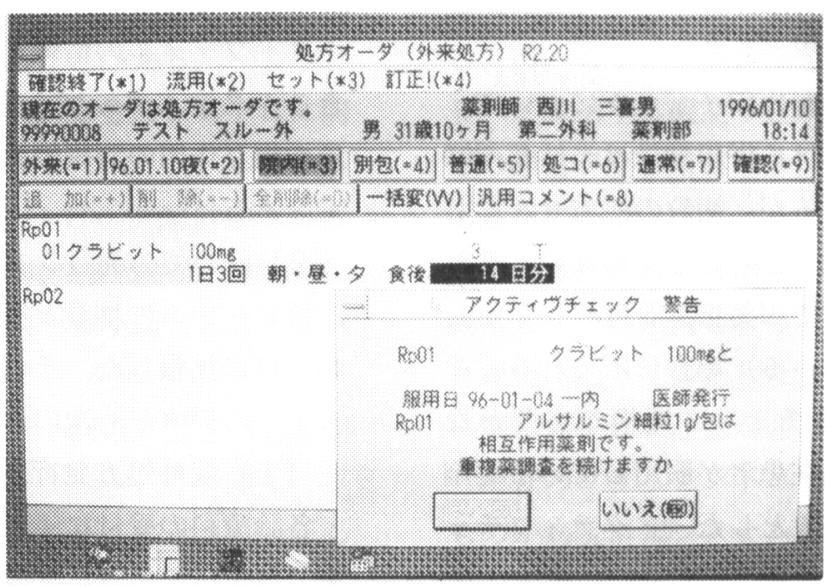

四 3。相五作用千ェック例 


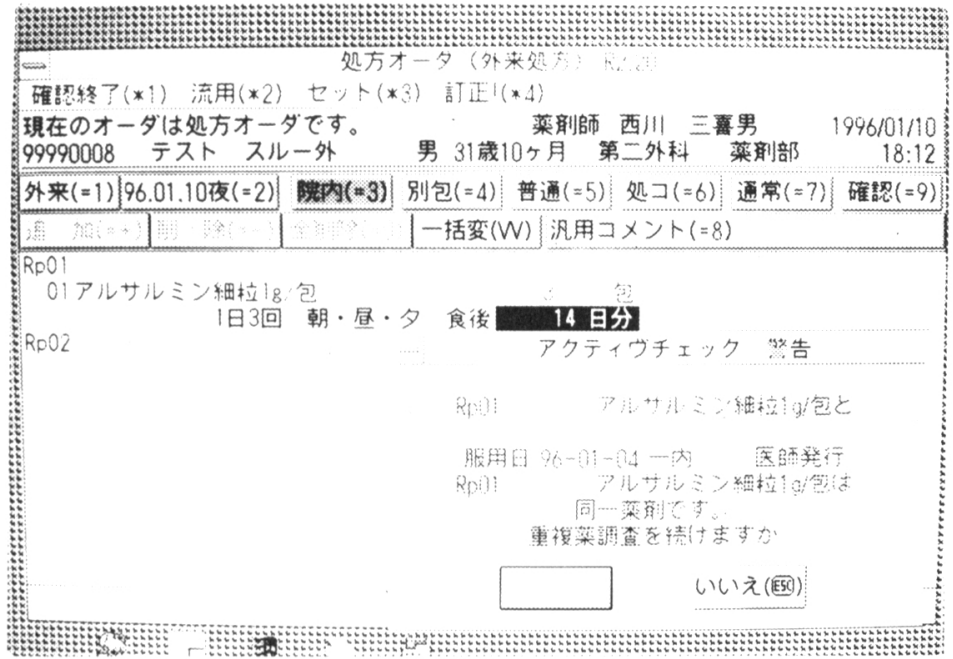

网 4.重複投与千エック例

ようになった。

（2）使用用紙の統一化

従来はプレプリントされた院外処方専用用紙を 用いていたが，検査結果出力も可能な A 4 の白 紙に A 5 判で出力することにした。

(3) 院外処方出力のスピード化

PC オーダリングでは䛦療終了時に処方せんが 出力されるのが標準であった。（2）の用紙統一 が一因となって, 当初は骖療終了してから約 2 分 が処方せん出力までに要する時間であった。ホス 卜との交信回数を増やすことで 1 分以内まで短縮 されたが，医師からの不満は解消することができ なかった。そこで，医師が処方登録した時点に処 方せんを発行し，それに医師が押印するシステム 運用に変更した。予約業務などを行っている間に 院外処方せんが出力され，時間の短縮が可能にな った。
まとめ

ホスト集中型からクライアント・サーバー型分 散システムへの移行には様々な問題が生じた。本 院のシステムが日本電気としては最初の取り組み であったこと，時間的余裕が少なかったことにそ の原因があると思われた。病院情報システムは患 者に直接影響を及ぼすものであるから，その開発 にかける時間が十分なくてはならないと確信し た。現在，いろいろな施設に扰いて，ホス卜集中 系からクライアント・サーバー型への変更が検討 されているが，この報告が同じような問題を生じ ないための一助になれば幸いである。

今回，アクティブチェックにより禁忌・相互作 用，重複チェックがレスポンスにほとんど影響を 与えることなく実現できたことは一つの前進であ る。患者の安全を考虑したより進んだシステムに していく予定である. 